\title{
日本住血吸虫病により肝肥大を呈せる 學童の舌及び皮膚の色調
}

Colour of Skin and Tongue of School Children with Liver Corpulence Affected by Schistosomiasis

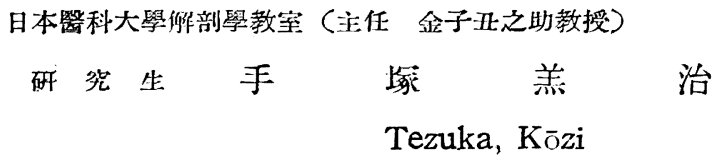
內 容目 次
第 I 章·緒 言
第 II 章 被检者並びに测定方法
a. 被檢 者
b. 测定方法
第 III 章 湘定成縉
A. 舌尖の色調出現箖图
B. 舌體の色調出現箱阔
C. 舌粘膜の主色調
D. 舌粘膜色調小括
E. 皮溥色調

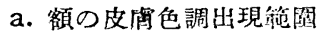

b. 上䛷内側の皮或色調出现筑图

F. 皮简色調小括

第 IV 章 總括世びに結論

主要交献

\section{第 I 章 緒訔}

皮虞色調が患者の現症及び豫後判定に必要缺 くべからざることは，すで當教室譛業績中に 詳載されその重複を要しないが, 舌粘膜色調も また臨床上特澺義梁いものであることは各臨 床醫家の齊しく日常經驗しているところで㐫 る。

古來舌の研究は多くの學者によつてなされそ の報告も實に枚擧に遑ないほどであるがその多 くは比較的な或は瞬昧な表現をもつてしたもの でこれれ色彩學的に扱つたものは余の察䦥え の報告を知らない。

余はさきに本邦人健常者の舌色調について學 會報告したが（原著は近く日本醫科大學雜誌發
姜の豫定),このたび日本住血吸虫病により肝肥 大苍呈せる學童の舌及び皮膚色調袁計測し，ゃ 〉見るべき結果在得たので敢てこ〉に報告し諸 賢の御批判と御敎示を乞うことにする。

\section{第 II 章，被檢者並びに測定方法}

a. 被檢者 山梨縣中巨摩郡八田小.中學校學 童生徒で，校醫の嚴重な身體檢查により肝肥大 邑呈し，現在就學中の 6 歳より15歳にいだる男 女合計 289 名の 8 ので, 各年砱別被檢者數を示 すと第 1 表の如くなる。

第 1 表 被检者の性別・年路別内譯

\begin{tabular}{|c|c|c|c|c|c|}
\hline 性 & 別 年 & 龄 67 & 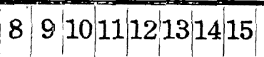 & 部 & 合計 \\
\hline & 今 & 1110 & $9292721234137 \quad 9$ & 195 & \multirow{2}{*}{289} \\
\hline & 우 & 122 & $8161111 / 219105$ & 94 & \\
\hline
\end{tabular}

b. 測定方法 計測《は金子皮膚比色計芭使用

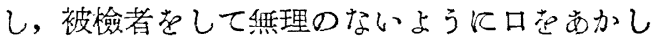
て舌孛出させ舌體及び舌尖出を測定するととも に，額及び上腕内側皮膚色さも併世行つた。こ のさい計測諸條件を格守することに努めた。

\section{第 III 章 測 定 成 績}

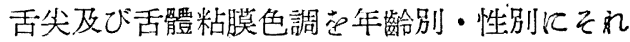
ぞれ色調の出現範圍, 主色調, 平均基礎色を示 すと下記の如くなる。

\section{A. 舌尖の色調出現範圍}

6歳令(11名): 5.76 6.00〔 $\mathrm{id}(1)]-6.01 \sim 6.25$ [ieid(1)-id (3)-idke(2)]-6.26 


$$
\sim 6.50[\mathrm{id}(2)-\mathrm{idke}(2)]
$$

우(12名): $5.76 \sim 6.00[\mathrm{id}(2)-\mathrm{idke}(1)]-6.0$

$1 \sim 6.25[\mathrm{id}(3)$-idke (1)]-6.26

$\sim 6.50[\mathrm{id}(2)-\mathrm{idke}(4)]$

7歳合(10名): 5.70 6.00[id (1)]-6.01 6.

$25[\operatorname{id}(2)-\operatorname{idke}(4)]-6.26 \sim 6.50$

[idke(3)]

우( 7 名): $5.76 \sim 6.00[$ idke (1)]-6.01

$6.25[\mathrm{id}(1)-\mathrm{idke}(2)]-6.26 \sim$

6.50[idke(3)]

8歳令( 9 名): $5.76 \sim 6.00[\mathrm{id}(2)]-6.01 \sim 6.25$

$[\mathrm{id}(2)-\mathrm{idke}(1)]-6.26 \sim 6.50[\mathrm{id}$

(3)-idke(1)]

우( 8 名): $5.76 \sim 6.00[\operatorname{idke}(1)]-6.01 \sim 6$.

$25[\mathrm{id}(3)-\mathrm{idke}(2)]-6.26 \sim 6.50$

[idke(2)]

9歳古(29名): 6.01 6.25[ieke (2)-id(13)idke(7)]-6.26 6.50[ieke(1)$\mathrm{id}(1)-\mathrm{idke}(5)]$

오(16名): $5.76 \sim 6.00[\mathrm{idke}(1)]-6.01 \sim 6$.

$25[\mathrm{id}(2)-\mathrm{idke}(7)]-6.26 \sim 6.50$

[id(1)-idke(4)]

10歳合(27名): 5.76 6.00[idke(1)]-)6.01〜

$6.25[$ id $(9)$-idke (7)]-6.26

$6.50[\mathrm{id}(1)$-idke(5)]

오(11名): $5.76 \sim 6.00[$ idke (1)]-6.01

6.25 [id (1)-idke (3)-6.26

$6.50[$ ieke(1)-idke(5)]

11歳古(21名): 6.01 6.25〔hdie (1)-hdid (1) $-i e i d(1)-i d(3)-i d k e(5)]$

우(11名): $6.01 \sim 6.25[\mathrm{id}(2)-\mathrm{idke}(3)]-6$.

$26 \sim 6.50[\mathrm{id}(1)-\mathrm{idke}(5)]$

12歳今(23名)：6.01 6.25(hdid (1)-iehe(2)id(3)-idke(6)]-6.26 6.50[hdie(1)-id(5)-idke(5)]

우(12名): 6.01 6.25〔ieid(2)-id(3)-idke

(1) $]-6.26 \sim 6.50[\mathrm{ie}(1)-\mathrm{id}(4)$

-idke(1)]

13歳古(41名): $5.76 \sim 6.00[\mathrm{id}(1)]-6.01 \sim 6.25$

[hdie(1)-iehe (3)-id (7)-idke

(7) $]-6.26 \sim 6.50[$ iehe $(4)-\mathrm{id}(4)$
$(413)-55-$

-idhe(13)-idkd(1)]

우(19名): $6.01 \sim 6.25[\mathrm{id}(1)-\mathrm{idke}(2)]-6$.

$26 \sim 6.50$ [ieke(1)-id (2)-idke

(6) $]-6.51 \sim 6.75$ [id (2)-idke

(1)]

14藏令(37名): $5.76 \sim 6.00[\operatorname{idke}(2)]-6.01 \sim 6$.

$25[\operatorname{ieke}(2)-\mathrm{id}(2)$-idke (9)]-

$6.26 \sim 6.50$ [ieke (2)-ieid (1)

-id(2)-idke(16)-ke(1)]

우(10名): $6.01 \sim 6.25$ [ieke(1)-id(1)-idke

(2) $-6.26 \sim 6.50[\mathrm{id}(1)-\mathrm{idke}(5)]$

15歳令 (9 名): 5.76 6.00[idke(2)]-6.01 6.

$25[\mathrm{id}(3)]-6.26 \sim 6.50[\operatorname{idke}(3)-$ $\mathrm{ke}(1)]$

우( 5 名): 6.01 6.25[idke(2)]-6.26 6. $50[\operatorname{idke}(3)]$

\section{B. 舌體の色調出現範圍}

6歳令(11名): $5.76 \sim 6.00[\operatorname{ieke}(1)]-6.01 \sim 6$. 25 [hdid(1)-ieke(5)-idke(1)] $-6.26 \sim 6.50[\operatorname{ieke}(2)-i \mathrm{dke}(1)]$

우(12名): $6.01 \sim 6.25$ ‘hdid (1)-ieke(4)ieid(2)-idke(2)-6.26 6.50[ie- . $\mathrm{ke}(1)-\mathrm{idke}(2)]$

7傶令(10名): $5.76 \sim 6.00[\mathrm{ieke}(1)]-6.01 \sim 6$. $25[\operatorname{hdie}(1)-i e k e(4)-i d k e(2)]-$ $6.26 \sim 6.50[\operatorname{ieke}(2)]$

우( 7 名): $6.01 \sim 6.25[\operatorname{ieke}(4)-\mathrm{id}(1)]-6$. $26 \sim 6.50[\operatorname{ieke}(2)]$

8 歳令 (9 名): $5.76 \sim 6.00[\operatorname{ieke}(1)]-6.01 \sim 6$. $25[\operatorname{ieke}(4)-\mathrm{id}(1)]-6.26 \sim 6.50$ [ieke(2)-idke(1)]

우( 8 名): $5.76 \sim 6.00[\mathrm{ieke}(2)]-6.01 \sim 6$. $25[\mathrm{ieke}(3)-\mathrm{id}(1)]-6.26 \sim 6.50$ [ieke(2)]

9藏古 (29名): 5.76 6.00[ieke(1)]-6.01〜6. 25[hdie(1)-ieke (19)-ieid(1)idke(1)]-6.26 -6.50 ieke(5)$\operatorname{ieid}(1)]$

우(16名): $5.76 \sim 6.00[\mathrm{ieke}(2)]-6.01 \sim 6$. 25[hdie(1)-ieke( 6$)$-ieid(1)-id 
(2) $]-6.26 \sim 6.50[\mathrm{ieke}(3)-\mathrm{id}(1)]$

10藏占(27名): 6.01 6.25〔hdie (2)-hdid(2)ieke(12)-ieid (3)-idke(1)] 6. $26 \sim 6.50$ [hdid (1)-ieke (4)$\operatorname{ieid}(2)]$

오(11名): $5.76 \sim 6.00$ [ieke (1) $-6.01 \sim$ 6.25 [ieke (5)-id (1)]-6.26 $6.50[\operatorname{ieke}(3)$-idke(1)]

11藏古(21名): 5.76 6.C $0[$ ieke (3)]-6.01 6. $25[\mathrm{hd}(1)-\mathrm{ie}(2)-\mathrm{ieke}(10)$ )$6.26 \sim 6.50[\operatorname{hdie}(1)-\operatorname{ieke}(4)]$

우(11名): 6.01 6.25[hdie(1)-ieke(4)ieid(2)]-6.26 6.50[ieke(3)-id (1)]

12歳合(23名): 5.76 6.00[hdie (1)-hdid(2)ieke(1)]-6.01 6. 25[hdie(2)$\operatorname{hdid}(3)-\operatorname{ieke}(3 ;-\mathrm{id}(1)-\mathrm{ke}(1)]$ $-6.26 \sim 6.50[$ hdie $(1)-\operatorname{hdid}(1)$ -ieke(5)-idke(1)-ke(1)]

우(12名): (.01 6.25〔hdie (1)-ieke (3)ieid(2)]-6.26 6.50[hdie (2)$\operatorname{ieke}(2)-\operatorname{ieid}(2)]$

13藏古(41名): 5.76 6.00 (hdie (1)-hdid(2)ieke(1)]-6. 01 6. 25[hdie(1)hdid (4)-ieke (13)-id(1)-idke (1)-idkd (1) $]-6.26 \sim 6.50[$ hdie (3) $-\operatorname{ieke}(12)-\operatorname{idke}(1)]$
우(17名): $6.01 \sim 6.25[\mathrm{ie}(2)$-ieke(6)-ieid (3)-idke(1)]-6. 26 6.50[ieke (4) $-\mathrm{id}(1)]$

14歳合(37名): 5.76 6.00[ieke(3)-idke(1)]$6.01 \sim 6.25[\operatorname{ieke}(14)$-idke(1)] 오(10名): $6.01 \sim 6.25[\operatorname{ieke}(5)]-6.26 \sim 6$. $50[\operatorname{ieke}(3)-\operatorname{idke}(2)]$

15歳合 (9 名): $5.76 \sim 6.00[\operatorname{ieke}(1)]-6.01 \sim 6$. $25[$ ieke(4)-ke (2)]-6.26 6.50 [ieke(3)]

우( 5 名): $5.76 \sim 6.00[\operatorname{ieke}(1)]-6.01 \sim 6$. $25[$ ieke'(3)]-6.26 6.50[ieke(1)]

\section{C. 舌粘膜の主色調}

䍜病學童(S)の舌體及び舌尖粘膜の主色調芑 年路別, 性別反裴示するとともに健常者のもの 併記して，その色調の對照に便ならしめた。

（第 2,3 表の如し）。

\section{D. 呫粘膜色調小括}

上記各表から次の如く要約される。郎ち

1)舌尖色調の色彩三角上飞於行万位置は hdie-ke-kd-id の範圍に西るが，idke が主として これる代表している。

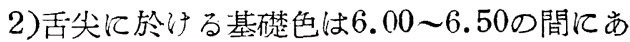
つて，各年齡に打汀平均基礎色は6.15 6.33 である。

第2 表 舌粘脱の主色調 ( $\mathrm{S}$ 一罹病者, $\mathrm{G}$ 一促管者)

\begin{tabular}{|c|c|c|c|c|c|c|c|c|c|c|c|}
\hline $\begin{array}{l}\text { 部 } \\
\text { 位 }\end{array}$ & 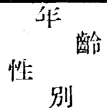 & 6 & 7 & 8 & 9 & 10 & 11 & 12 & 13 & 14 & 15 \\
\hline 舌 & $\begin{array}{ll} & s \\
& G\end{array}$ & $\begin{array}{l}6.25 \\
\text { ieke } \\
6.25 \\
\text { ieke }\end{array}$ & $\begin{array}{l}6.25 \\
\text { ieke } \\
6.25 \\
\text { ieke }\end{array}$ & $\begin{array}{c}6.25 \\
\text { ieke } \\
6.30 \\
\text { ieke }\end{array}$ & $\begin{array}{l}6.25 \\
\cdot \text { ieke } \\
6.30 \\
\text { ieke }\end{array}$ & $\begin{array}{c}6.25 \\
\text { ieke } \\
6.30 \\
\text { ieke }\end{array}$ & $\begin{array}{c}6.25 \\
\text { ieke } \\
6.30 \\
\text { ieke }\end{array}$ & $\begin{array}{c}6.25 \\
\text { ieke } \\
6.30 \\
\text { ieke }\end{array}$ & $\begin{array}{c}6.25 \\
\text { ieke } \\
6.30 \\
\text { ieke }\end{array}$ & $\begin{array}{c}6.25 \\
\text { ieke } \\
6.30 \\
\text { ieke }\end{array}$ & $\begin{array}{l}6.25 \\
\text { ieke } \\
6.30 \\
\text { ieke }\end{array}$ \\
\hline 體 & 우 $\begin{array}{ll}\mathrm{S} \\
\mathrm{G}\end{array}$ & $\begin{array}{l}6.25 \\
\text { ieke } \\
6.25 \\
\text { ieke }\end{array}$ & $\begin{array}{l}6.25 \\
\text { ieke } \\
6.25 \\
\text { ieke }\end{array}$ & $\begin{array}{c}6.25 \\
\text { ieke } \\
6.30 \\
\text { ieke }\end{array}$ & $\begin{array}{c}6.25 \\
\text { ieke } \\
6.25 \\
\text { ieke }\end{array}$ & $\begin{array}{c}6.25 \\
\text { ieke } \\
6.25 \\
\text { ieke }\end{array}$ & $\begin{array}{c}6.25 \\
\text { ieke } \\
6.30 \\
\text { ieke }\end{array}$ & $\begin{array}{c}6.25 \\
\text { ieke } \\
6.30 \\
\text { ieke }\end{array}$ & $\begin{array}{l}6.25 \\
\text { ieke } \\
6.30 \\
\text { ieke }\end{array}$ & $\begin{array}{c}6.25 \\
\text { ieke } \\
6.30 \\
\text { ieke }\end{array}$ & $\begin{array}{l}6.25 \\
\text { ieke } \\
6.30 \\
\text { ieke }\end{array}$ \\
\hline 舌 & $\begin{array}{l}S \\
G\end{array}$ & $\begin{array}{c}6.25 \\
\text { idke } \\
6.25 \\
\text { id }\end{array}$ & $\begin{array}{l}6.25 \\
\text { idke } \\
6.30 \\
\text { idke }\end{array}$ & $\begin{array}{l}6.25 \\
\text { idke } \\
6.30 \\
\text { id }\end{array}$ & $\begin{array}{l}6.25 \\
6.25 \\
\text { id }\end{array}$ & $\begin{array}{l}6.25 \\
\text { id } \\
6.30 \\
\text { idke }\end{array}$ & $\begin{array}{c}6.30 \\
\text { idke } \\
6.30 \\
\text { idke }\end{array}$ & $\begin{array}{c}6.30 \\
\text { idke } \\
6.25 \\
\text { id }\end{array}$ & $\begin{array}{l}6.30 \\
\text { idke } \\
6.30 \\
\text { idke }\end{array}$ & $\begin{array}{c}6.30 \\
\text { idke } \\
6.30 \\
\text { idke }\end{array}$ & $\begin{array}{c}6.30 \\
\text { idke } \\
6.30 \\
\text { idke }\end{array}$ \\
\hline 尖 & 우 $\begin{array}{ll}\mathrm{S} \\
& \mathrm{G}\end{array}$ & $\begin{array}{l}6.30 \\
\text { idke } \\
6.30 \\
\text { id }\end{array}$ & $\begin{array}{c}6.30 \\
\text { idke } \\
6.25 \\
\text { idke }\end{array}$ & $\begin{array}{l}6.25 \\
\text { idke } \\
6.30 \\
\text { id }\end{array}$ & $\begin{array}{c}6.30 \\
\text { idke } \\
6.25 \\
\text { idke }\end{array}$ & $\begin{array}{c}6.30 \\
\text { idke } \\
6.30 \\
\text { idke }\end{array}$ & $\begin{array}{c}6.30 \\
\text { idke } \\
6.30 \\
\text { idke }\end{array}$ & $\begin{array}{c}6.30 \\
6.30 \mathrm{id} \\
\mathrm{id}\end{array}$ & $\begin{array}{l}6.30 \\
\text { idke } \\
6.30 \\
\text { id }\end{array}$ & $\begin{array}{l}6.30 \\
\text { idke } \\
6.30 \\
\text { idke }\end{array}$ & $\begin{array}{c}6.30 \\
\text { idke } \\
6.30 \\
\text { idke }\end{array}$ \\
\hline
\end{tabular}


第 3 表 舌蹬及び舌尖粘膜の平均基礎色( S一羅病者, G一健常者)

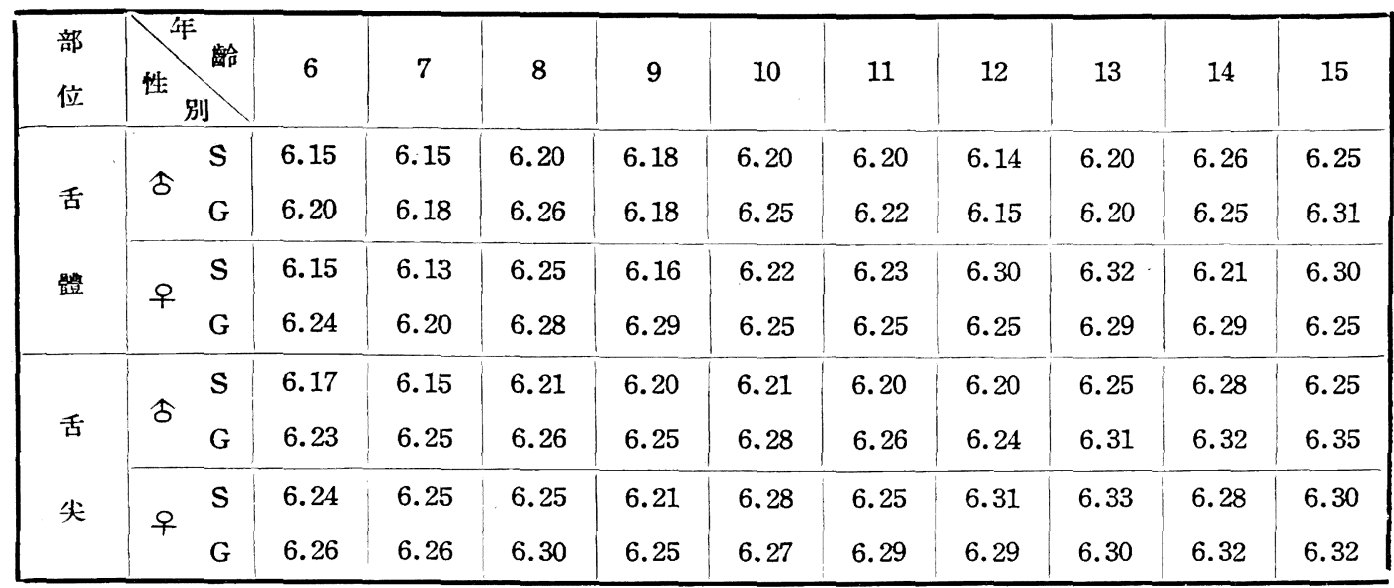
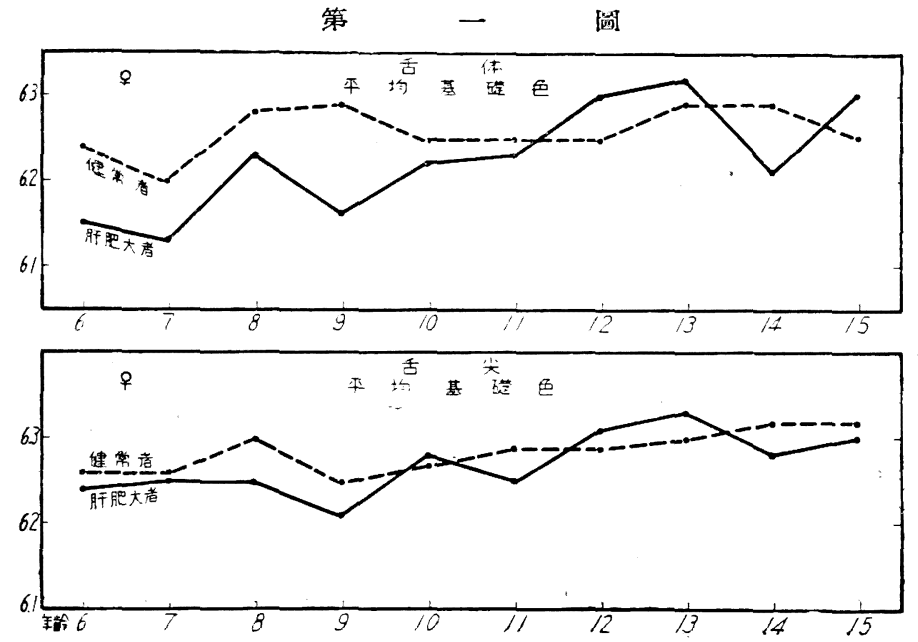

第 二 阔
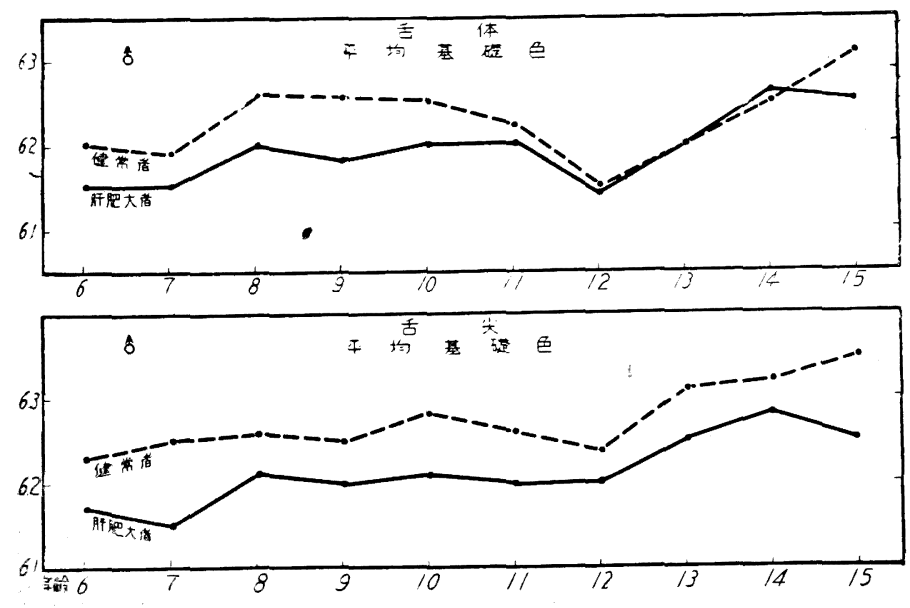

3)舌䱏色調の色彩三看汇於 ける位置は hd-ie-ke-kd-id

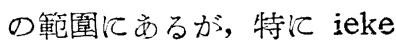
の頻度が高い。

4)舌䯣の 基礎色は 6.00 6.75 の間にあり, 各年齡に

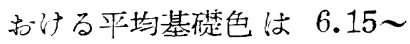
6.32 である。

5)舌尖の純色含有量は 27 $\because \sim 31 \%$, 白含有量は $12 \%$ $15 \%$, 黑含有量は $55 \%$ \% 吅であつて，男女間に大差が 認められない。

6)舌縉の純色含有量は 24 $\% \sim 30 \%$, 白含有量は $12 \%$ 〜 16\% , 黑会量は $55 \%$ ～65\% でめつて，著しき性差地認め ない。

\section{E. 皮境色調}

客面，上腕内側皮膚色調年 路别，性别に色调の出現範 圍・主色調・平均基礁色の順 に示市と下記の如くで市る。

\section{a.額の皮呞色調出現铯圍}

6 歳今(11名)：3.00-3.25-3. 50-3. 75 (hd- 


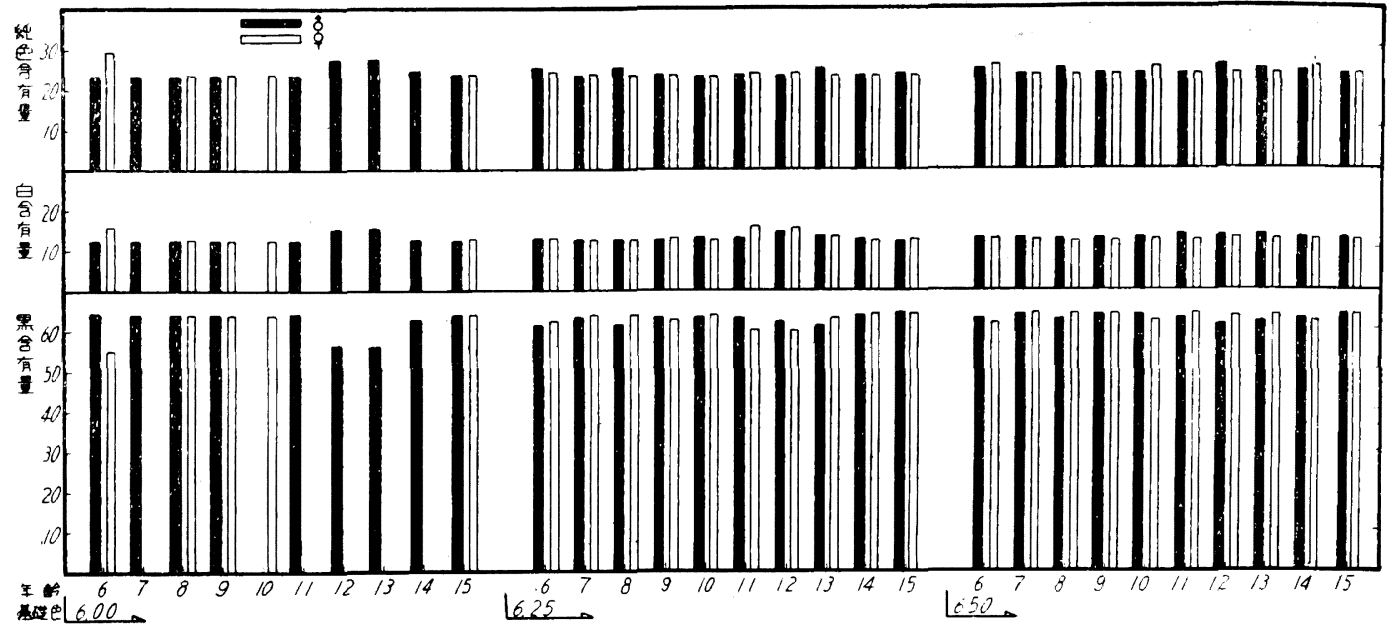

第四湔肝肥大者舌體色調の分折合有量

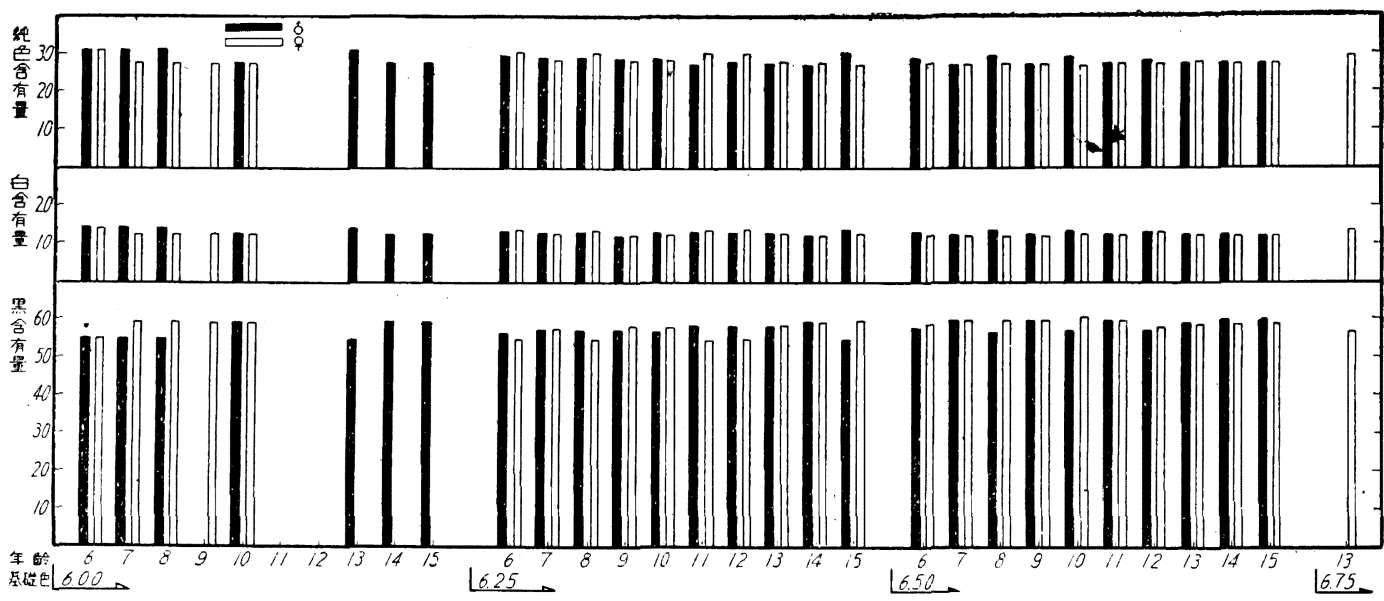

hdie)

우(12名): 3.00-3.25-3.50-3.75(gc-hd)

7 歳令(10名): 3. (0)-3.25-3.50-3.75(hd-hdieid)

우( 7 名): 3.00-3.25-3.50-3.75(gchd-hd) 8 歳占 (9 名): 3.00-3.25-3.50-3.75(hd-hdid)

우( 8 名): $3.00-3.25-3.50-3.75$ (gchd-hd) 9 藏古(29名): 3.00-3.25-3.50-3.75(gchd-hdhdid-hdie)

우(16名): $3.03-3.25-3.5-3.75-4.0 \simeq(\mathrm{gc}-$ gchd-hd-hdid)

10歳含(27名): 3.00-3.25-3.50-3.75(gc-gchd- hd-hdid)

우(11名): 3.00-3.25-3.50-3.75(hd-hdidhdie)

11歳合(21名): 3.00-3.25-3.50-3.75(gchd-hdhdid-hdiè)

우(11名): 3.00-3.25-3.50-3.75(gchd-hdhdid)

12歳今(23名): 3.0c-3.25-3.5c-3.75(gchd-gdhd-hdie-id)

우(12名): $3.00-3.25-3.50-3.75$ ( $\mathrm{gchd}-\mathrm{hd}$ hdid)

13歳令(41名): $3.00-3.25-3.50-3.75$ (gchd-gd- 


$$
\text { (417) }-59-
$$

gdhd-hd-hdie)

우(19名): $3.00-3.25-3.50-3.75$ (gchd-gdhd-hdid)

14歳含(37名)：3.00-3.25-3.50-3.75-4.0 (gchd-gd-gdhd-hd-hdie)

우(10名): 3.00-3.25-3.50-3.75(gd-hd)

15歳古 ( 9 名): 3.00-3.25-3.50-3.75(hd)

우( 5 名): 3.25-3.50-3.75(hd)

\section{b. 上腕內側の皮属色調出現範圍}

6 歳占(11.名): $3.00-3.25-3.50$ (gc-gchd-hd)

우(12名): $3.00-3.25-3.50-3.75$ (gc-gchdhd)

7 歳古(10名): 3.0c-3.25-3.50(hd-hdie)

우( 7 名): $3.00-3.25-3.50$ (hd)

8 歳古( 9 名): 3.00-3.25-3.50(hd)

우( 8 名): 3.00-3.25-3.50(gdhd-hd)

9 歳合 (29名): 3.00-3.25-3.50 (fcgc-gchd-rdhdid-hdie-he)

우(16名): 3.00-3.25-3.50-3.75 (gc-gchdhd-hdid)

10歳古(27名): 3.00-3.25-3.50 (gc-gchd-gd hd-hd)

우(11名): 3.0c-3.25-3.5c-3.75 (gchd-hdhdie)

11歳古(21名): 3.00-3.25-3.50-3.75-4.00(gchd-gd-hd-hdie)

우(11名): 3.00-3.25-3.50-3.75 (gchd-hdhdid)

12歳含(23名)：3.00-3.25-3.50-3.75(gc-gchdhd)

우(12名): $3.00-3.25-3.50$ (gchd-hd)
13歳含(41名): 3.00-3.25-3.50-3.75(fcgd-gcgchd-gdge-hd)

우(19名): $3.00-3.25-3.50-3.75$ (gc-gchdgd-hd-hdid)

14歳合(37名): 3. 00-3.25-3.50-3.75(fcgd-gcgchd-gd-gdhd-hd-hdid)

우(10名): $3.00-3.25-3.50-3.75$ (gchd-gdhd)

15歳古 ( 9 名): 3.00-3.25-3.50-3.75(gchd-gdhd-hd-hdie)

오( 5 名): 3.25-3.50-3.75(hd)

\section{F. 皮属色調小括}

第 4, 5，6， て表加次の如く要約市るこ とができる。

a) 額の色調

1)色彩三角に於行万位置付 gc-hd-ie-id の範 图にあつて主として hdがこれ代表している。

2)基礎色は 3.00 3.75 の間汇あつて各年齡 にお汁る平均基礎色は 3.25 3.50 で弟る。

3 純色含有量は $25 \%$ ～32\%, 白含有量は $15 \%$ 〜 19\%，黑含有量は 55\% 60\% で文る。

b）上腕内側の色調

1)色彩三角浪於方位置は gc-hd-ie-id の 範圍にあつて，主として hd がこれ路代表して いる。

2)基礎色は 3.00〜4.00 の間にあつて，各年 龄汇おける平均基礎色は 3.20 3.52 である。

3)純色含有量は $25.9 \%$ ～30.3\% , 白会有量は $15.8 \%$ ～19.9\%，黑含有量は $49.8 \%$ ５0.8\%で ある。

\section{第 IV 章 綜括並ひに結論}

第 4 表 額の主色調 (S一䍜病者, G一健帕者)

\begin{tabular}{|c|c|c|c|c|c|c|c|c|c|c|c|}
\hline 性 & 齡 & 6 & 7 & 8 & 9 & 10 & 11 & 12 & 13 & 14 & 15 \\
\hline 今 & $\begin{array}{l}S \\
G\end{array}$ & $\begin{array}{l}3.40 \\
\text { hd } \\
3.40 \\
\text { hd }\end{array}$ & $\begin{array}{l}3.40 \\
\text { hd } \\
3.45^{\text {hd }}\end{array}$ & $\begin{array}{c}3.40 \\
\text { hd } \\
3.45 \\
\text { hd }\end{array}$ & $\begin{array}{l}3.65 \\
\text { hd } \\
3.45 \\
\text { hd }\end{array}$ & $\begin{array}{c}3.65 \\
\text { hd } \\
3.45 \\
\text { hd }\end{array}$ & $\begin{array}{r}3.65 \\
\text { hd } \\
3.45 \\
\text { hd }\end{array}$ & $\begin{array}{c}2.65 \\
\text { hd } \\
3.65 \\
\text { hd }\end{array}$ & $\begin{array}{c}3.65 \\
\text { hd } \\
3.65 \\
\text { hd }\end{array}$ & $\begin{array}{c}3.78 \\
\text { hd } \\
3.65 \\
\text { hd }\end{array}$ & $\begin{array}{c}3.65 \\
\text { hd } \\
3.65 \\
\text { hd }\end{array}$ \\
\hline 오 & $\begin{array}{l}\mathrm{S} \\
\mathrm{G}\end{array}$ & $\begin{array}{c}3.40 \\
\text { hd } \\
3.40 \\
\text { hd }\end{array}$ & $\begin{array}{c}3.65 \\
\text { hd } \\
3.45 \\
\text { hd }\end{array}$ & $\begin{array}{c}3.40 \\
\text { hd } \\
3.45 \\
\text { hd }\end{array}$ & $\begin{array}{c}3.65 \\
\mathrm{hd} \\
3.40 \\
\mathrm{hd}\end{array}$ & $\begin{array}{c}3.65 \\
\text { hd } \\
3.40 \\
\text { hd }\end{array}$ & $\begin{array}{c}3.65 \\
\mathrm{hd} \\
3.40 \\
\mathrm{hd}\end{array}$ & $\begin{array}{c}3.65 \\
\text { hd } \\
3.65 \\
\text { hd }\end{array}$ & $\begin{array}{c}3.65 \\
\text { hd } \\
3.65 \\
\text { hd }\end{array}$ & $\begin{array}{c}3.65 \\
\text { hd } \\
3.65 \\
\text { hd }\end{array}$ & $\begin{array}{c}3.65 \\
\text { hd } \\
3.95 \\
\text { hd }\end{array}$ \\
\hline
\end{tabular}


$-60-(418)$

第 5 表 上腕内側の主色調 ( $S$ 一䍜病者, G一健常者)

\begin{tabular}{|c|c|c|c|c|c|c|c|c|c|c|c|}
\hline 性 & & 6 & 7 & 8 & 9 & 10 & 11 & 12 & 13 & 14 & 15 \\
\hline 今 & $\begin{array}{l}S \\
G\end{array}$ & $\begin{array}{c}3.40 \\
\mathrm{hd} \\
3.65 \\
\mathrm{hd}\end{array}$ & \begin{tabular}{|c|}
3.45 \\
$\mathrm{hd}$ \\
3.65 \\
$\mathrm{hd}$
\end{tabular} & $\begin{array}{c}3.45 \\
\mathrm{hd} \\
3.65 \\
\mathrm{hd}\end{array}$ & $\begin{array}{c}3.45 \\
\text { hd } \\
3.65 \\
\text { hd }\end{array}$ & $\begin{array}{c}3.45 \\
\text { hd } \\
3.65 \\
\text { bd }\end{array}$ & $\begin{array}{c}3.40 \\
\mathrm{hd} \\
3.65 \\
\mathrm{hd}\end{array}$ & \begin{tabular}{|c|}
3.45 \\
$\mathrm{hd}$ \\
3.65 \\
$\mathrm{hd}$
\end{tabular} & $\begin{array}{c}3.45 \\
\text { hd } \\
3.65 \\
\text { hd }\end{array}$ & $\begin{array}{c}3.45 \\
\text { gchd } \\
3.65 \\
\text { hd }\end{array}$ & $\begin{array}{l}3.45 \\
\mathrm{hd} \\
3.65 \\
\mathrm{hd}\end{array}$ \\
\hline 우 & $\begin{array}{l}S \\
G\end{array}$ & $\begin{array}{l}3.40 \\
\mathrm{hd} \\
3.40 \\
\mathrm{hd}\end{array}$ & $\begin{array}{l}3.45 \\
\text { hd } \\
3.65 \\
\text { hd }\end{array}$ & $\begin{array}{l}3.45 \\
\mathrm{hd} \\
3.65 \\
\mathrm{hd}\end{array}$ & $\begin{array}{c}3.45 \\
\mathrm{hd} \\
3.65 \\
\mathrm{hd}\end{array}$ & $\begin{array}{c}3.45 \\
\mathrm{hd} \\
3.65 \\
\mathrm{hd}\end{array}$ & $\begin{array}{c}3.45 \\
\mathrm{hd} \\
3.65 \\
\mathrm{hd}\end{array} \mid$ & $\begin{array}{c}3.45 \\
\mathrm{hd} \\
3.65 \\
\mathrm{hd}\end{array}$ & $\begin{array}{c}3.45 \\
\mathrm{hd} \\
3.65 \\
\mathrm{hd}\end{array}$ & $\begin{array}{c}3.45 \\
\text { gchd } \\
3.65 \\
\text { gchd }\end{array}$ & $\begin{array}{l}3.45 \\
\mathrm{hd} \\
3.65 \\
\mathrm{hd}\end{array}$ \\
\hline
\end{tabular}

第 6 表 额の平均基礎色 (S一罹病者, G一健常者)

\begin{tabular}{|c|c|c|c|c|c|c|c|c|c|c|c|}
\hline 性 & & 6 & 7 & 8 & 9 & 10 & 11 & 12 & 13 & 14 & 15 \\
\hline \multirow{2}{*}{ 今 } & $\mathrm{S}$ & 3.35 & 3.45 & 3.48 & 3.49 & 3.47 & 3.40 & 3.49 & 3.53 & 3.63 & 3.65 \\
\hline & G & 3.40 & 3.45 & 3.49 & 3.55 & 3.48 & 3.43 & 3.53 & 3.55 & 3.59 & 3.53 \\
\hline \multirow{2}{*}{ 우 } & $S$ & 3.39 & 3.45 & 3.47 & 3.47 & 3.46 & 3.45 & 3.56 & 3.72 & 3.82 & 3.82 \\
\hline & $\mathrm{G}$ & 3.39 & 3.53 & 3.46 & 3.51 & 3.48 & 3.50 & 3.50 & 3.45 & 3.50 & 3.55 \\
\hline
\end{tabular}

第 7 表 上腕内侧の平均基礎色 ( $\mathrm{S}$ 一䍜病者, $\mathrm{G}$ 一健常者)

\begin{tabular}{|c|c|c|c|c|c|c|c|c|c|c|c|}
\hline 性 & |J & 6 & 7 & 8 & 9 & 10 & 11 & 12 & 13 & 14 & 15 \\
\hline \multirow{2}{*}{ 今 } & $\mathrm{S}$ & 3.35 & 3.47 & 3.42 & 3.48 & 3.42 & 3.45 & 3.45 & 3.45 & 3.53 & 3.53 \\
\hline & $\mathrm{G}$ & 3.39 & 3.52 & 3.46 & 3.51 & 3.48 & 3.41 & 3.47 & 3.52 & 3.56 & 3.52 \\
\hline \multirow{2}{*}{ 우 } & $\mathrm{s}$ & 3.38 & 3.42 & 3.43 & 3.52 & 3.51 & 3.48 & 3.46 & 3.50 & 3.51 & 3.67 \\
\hline & G & 3.33 & 3.51 & 3.47 & 3.50 & 3.47 & 3.46 & 3.51 & 3.45 & 3.55 & 3.53 \\
\hline
\end{tabular}

著者は日本住血吸虫病により肝肥大を呈せる 學童 6 歳より 15 藏にいたる男女合計 289 名の 舌尖・舌體の粘膜及び額・上腕内側の皮膚色調 を金子皮覤比色計苍用い，下記の如き結論を得 た。郎ち

1.舌尖及び舌體粘膜の主色調並びにその出現 範圍(各項參照)。

2. 額及び上腕内側皮膚の主色調並びにその出 現範圍(各項參照)。

3. 犤病學童舌粘膜及び皮䖉色調の平均基礎色 は，いすれも一般に健常者のものに比して 低い。

4.色調の色彩三角上に扎ける位置は健常者の ものと大差ないが，ぞちらかといえば心持 ち左偏上向の傾向が見られる。
撋筆に市たり，終始御愁篤な御指導と御校閲 を賜つた恩師金子丑之助教授に萬腔の謝意点 する。

$$
\text { 主要 文 献 }
$$

1) 大島信道: 日本矮科大學雜誌第 18 巻第 3 號

2) 米永 喬: 日本疑科大學雜誌第 18 巻第 3 號

3) 根岸金吾 : 日本祭科大學雜誌第19巻第 1 號

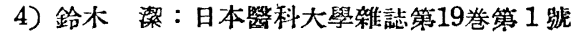

5) 芦田四郎：名古屋醫會誌第44巻第 6 號

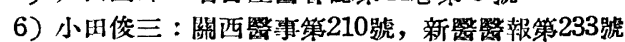

7) 太田・谷口：皮䖉泌尿器科雜誌第 5 號

8）檤口成正：内外治療第 3 號

9）荒井 菑：臨床日本第 2 巻第 14 號

10）近藤：診斷治療第21巻第 8 號

11) 王置：治療誌第 3 巻第11號

12）佐藤 享 : 治療醫學大正 8 年第12號

13）太田正雄：耳鼻咽喉科第 1 巻第 2 號 その他手塚羔治 : 舌の色調文献參照。 